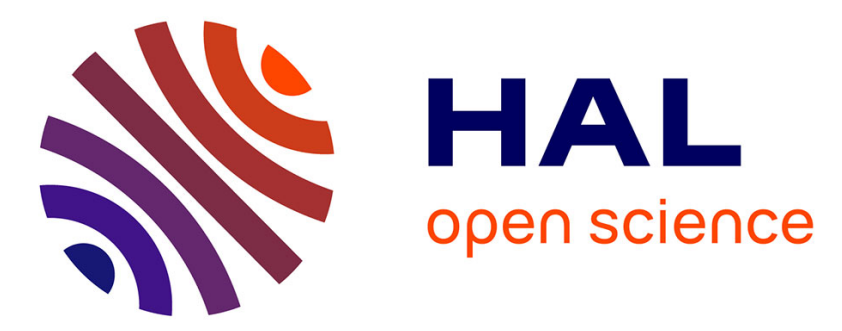

\title{
Acute abdomen and severe lactic acidosis can lead to a surprising diagnosis
}

Boris Jung, Lana Zoric, Gerald Chanques, Amadou Konate, David Nocca, Samir Jaber

\section{- To cite this version:}

Boris Jung, Lana Zoric, Gerald Chanques, Amadou Konate, David Nocca, et al.. Acute abdomen and severe lactic acidosis can lead to a surprising diagnosis. Intensive Care Medicine, 2010, 36 (1), pp.169-170. 10.1007/s00134-009-1631-0 . hal-02550562

\section{HAL Id: hal-02550562 \\ https://hal.umontpellier.fr/hal-02550562}

Submitted on 22 Apr 2020

HAL is a multi-disciplinary open access archive for the deposit and dissemination of scientific research documents, whether they are published or not. The documents may come from teaching and research institutions in France or abroad, or from public or private research centers.
L'archive ouverte pluridisciplinaire HAL, est destinée au dépôt et à la diffusion de documents scientifiques de niveau recherche, publiés ou non, émanant des établissements d'enseignement et de recherche français ou étrangers, des laboratoires publics ou privés. 
Boris Jung

Lana Zoric

Gerald Chanques

Amadou Konate

David Nocca

Samir Jaber

\section{Acute abdomen and severe lactic acidosis can lead to a surprising diagnosis}

Sir,

We report a case of a patient admitted for acute abdominal pain (suspected to be a "surgical abdomen") and severe lactic acidosis without sepsis that led to the diagnosis of a nonHodgkin lymphoma (NHL), a picture poorly described [1].

A 79-year-old man was admitted to the intensive care unit (ICU) for generalized abdominal tenderness, acute respiratory failure, lactic acidosis and refractory hypoglycemia 2 weeks after his admission to the ward for asthenia, weight loss and hypoglycemia. He was obese, presented diabetes mellitus, hypertension, chronic obstructive pulmonary disease and chronic heart failure.

On ICU admission, he had blood pressure $120 / 70 \mathrm{mmHg}$, heart rate 108 beats/min, respiratory rate 50 breaths/min and Glasgow Coma Score 12 without focalized neurological deficit. Abdominal examination revealed a generalized tenderness with intra-abdominal pressure below $15 \mathrm{mmHg}$ without liver or spleen abnormality. Due to refractory hypoglycemia, his diabetes treatment (metformin) was discontinued. Laboratory test results during hospitalization in the ICU are detailed in Table 1. A CT scan showed an infiltration of the sigmoid wall with fluid in the pouch of Douglas. Facing generalized abdominal tenderness with lactic acidosis, a laparotomy was performed, but did not reveal any

Table 1 Biological parameters during the ICU course

\begin{tabular}{lllll}
\hline & ICU admission & Day 1 & Day 2 & Day 3 \\
\hline $\mathrm{pH}$ & 7.43 & 7.29 & 7.41 & 7.26 \\
$\mathrm{PaCO}_{2}(\mathrm{mmHg})$ & 31 & 30 & 30 & 35 \\
Bicarbonates $(\mathrm{mmol} / \mathrm{l})^{\text {Uricemia }(\mu \mathrm{mol} / \mathrm{l})}$ & 20 & 14 & 19 & 15 \\
Corrected calcemia $(\mathrm{mmol} / \mathrm{l})$ & $\mathrm{NA}$ & $\mathrm{NA}$ & $\mathrm{NA}$ & 562 \\
Phosphoremia $(\mathrm{mmol} / \mathrm{l})$ & 2.7 & $\mathrm{NA}$ & 2.8 & 2.9 \\
Lactatemia $(\mathrm{mmol} / \mathrm{l})$ & 1.24 & 0.93 & 0.98 & 1.27 \\
SGOT $(\mathrm{IU} / \mathrm{l})$ & 7.6 & 7.4 & 9.2 & 10 \\
SGPT $(\mathrm{IU} / \mathrm{l})$ & 215 & 148 & 251 & 305 \\
LDH $(\mathrm{IU} / \mathrm{l})$ & 57 & 31 & 33 & 35 \\
Total bilirubinemia( $\mu \mathrm{mol} / \mathrm{l})$ & 8,599 & 5,872 & 8,452 & 10,185 \\
Conjugated bilirubinemia $(\mu \mathrm{mol} / \mathrm{l})$ & 53 & 54 & 101 & 153 \\
C-reactive proteine $(\mathrm{mg} / \mathrm{l})$ & 39 & 43 & 96 & 134 \\
Hemoglobin $(\mathrm{g} / \mathrm{l})$ & 170 & 117 & 147 & 158 \\
Platelets $\left(/ \mathrm{mm}^{3}\right)$ & 107 & 98 & 115 & 106 \\
Leukocytes $\left(/ \mathrm{mm}^{3}\right)$ & 59,000 & 41,000 & 52,000 & 14,000 \\
Lymphocytes $\left(/ \mathrm{mm}^{3}\right)$ & 25,100 & 19,600 & 19,100 & 11,400 \\
Prothrombine time $(\%)$ & 2,510 & $\mathrm{NA}$ & $\mathrm{NA}$ & 2,010 \\
Factor V $(\%)$ & 33 & 24 & 31 & 30 \\
\hline
\end{tabular}

$N A$ Not available

abnormalities. Persistent thrombocytopenia, lactic acidosis, elevated serum LDH and hypoglycemia without liver failure or ongoing sepsis led to the performance of a bone-marrow biopsy and a liver biopsy, which revealed a stage IV diffuse large B cell lymphoma with hemophagocytosis. Despite the multiorgan failure related to an aggressive lymphoma, which usually should be treated with aggressive chemotherapy, and because of severe comorbidities and a bad performance status, all specific chemotherapies for NHL were not administered as a first-line therapy. Nevertheless, the patient received $2 \mathrm{mg} / \mathrm{kg} /$ day of intravenous methylprednisolone to decrease the tumor cell mass. Unfortunately, the patient's condition continued to worsen, leading to death at day 3 after admission.

Generalized abdominal tenderness associated with lactic acidosis is mostly due to a surgical emergency [2]. In this case, the laparotomy eliminated a surgical disease, and a non-dysoxia lactic acidosis (type B) was considered. Lactic acidosis, initiated by an imbalance between lactic acid production and utilization, is often believed to be ischemic, anaerobically metabolizing tissues, among which the gut and muscle are popular suspects [2]. However, evidence argues that lactic acidosis as the result of anoxia or dysoxia (type A) is the exception rather than the rule [3]. Furthermore, evidence for the gut as a source of lactate is limited and almost certainly confounded by concurrent use of beta agonists, e.g., adrenaline [2]. Type B lactic acidosis is related to a toxin (biguanides, alcohols, propofol, antiretroviral nucleoside analogues), metabolic disorder (errors of metabolism) or underlying disease (kidney or renal failure, hematological malignancy) [1-3]. When lactic acidosis is coupled with hypoglycemia, errors of metabolism involving exaggerated glycolysis are often 
suspected [1, 3]. Overexpressed glycolytic enzymes, upregulation of insulin growth factor and an increased level of tumor necrosis factor $\alpha$ are the main mechanisms described in hematological malignancy cells to explain lactate hyperproduction through exaggerated glycolysis $[1,3,4]$. In this case, lactic acidosis could be related to hemophagocytosis, spontaneous and steroid-induced tumor lysis syndrome and lymphoma per se $[1,5]$.

In conclusion, in case of nondysoxia-related lactic acidosis, persistent thrombocytopenia and elevated levels of LDH, high grade tumors including hematological malignancy should be considered.

\section{References}

1. Friedenberg AS, Brandoff DE, Schiffman FJ (2007) Type B lactic acidosis as a severe metabolic complication in lymphoma and leukemia: a case series from a single institution and literature review. Medicine (Baltimore) 4:225-232

2. De Backer D (2003) Lactic acidosis. Intensive Care Med 5:699-702

3. Gladden LB (2004) Lactate metabolism: a new paradigm for the third millennium. J Physiol Pt 1:5-30

4. Evans LS, Hancock BW (2003) NonHodgkin lymphoma. Lancet 9378:139146

5. Creput C, Galicier L, Buyse S, Azoulay E (2008) Understanding organ dysfunction in hemophagocytic lymphohistiocytosis. Intensive Care Med 7:1177-1187
B. Jung (®) - L. Zoric •

G. Chanques $\cdot$ S. Jaber

Anesthesia and Intensive Care Unit,

Montpellier University Hospital,

80 av Fliche, 34295 Montpellier, France

e-mail: borisjung@dbmail.com

Tel.: +33-467337271

Fax: $+33-467337448$

\section{A. Konate}

Internal Medicine Department, Montpellier

University Hospital, Montpellier, France

D. Nocca

Abdominal and Bariatric Surgery Department, Montpellier University Hospital,

Montpellier, France 